\title{
Perennial Philosophy and Christianity
}

(C) 2007 James S. Cutsinger

Published in Christianity: The Complete Guide, ed. John Bowden (London: Continuum, 2005)

Theologians and philosophers of religion have understood the perennial philosophy in two distinct ways. Among Roman Catholic writers, those influenced in particular by the teachings of St Thomas Aquinas, it is often associated with the classical heritage of ancient Greece and Rome and refers to beliefs about God, human nature, virtue, and knowledge that church fathers and medieval scholastics share with pre-Christian philosophers, notably Plato and Aristotle. The Latin expression philosophia perennis, 'perennial philosophy', was probably first employed in this sense by Agostino Steucho (1496-1549), a Vatican librarian, and was given currency in the early eighteenth century by the philosopher Leibniz. More recently, the phrase has been used in a broader way to refer to the idea that all of the world's great religious traditions are expressions of a single, saving truth. Comparing this truth to a perennial flower, a perennialist asserts that there is one divine Source of all wisdom, which has repeatedly blossomed forth throughout history. The major religions, including Hinduism, Buddhism, Taoism, Judaism, Christianity, and Islam, are different forms of that wisdom and are sometimes referred to as paths leading to the same summit or dialects of a common language.

Understood in this second sense, the perennial philosophy was popularized in the twentieth century by Aldous Huxley in a book by that title (1946). Its best known and most authoritative exponents, however, are Ananda Coomaraswamy, René Guénon, and especially Frithjof Schuon, whose Transcendent Unity of Religions (1948) has been of signal importance in defining the contemporary perennialist viewpoint. According to Schuon and those of his school, a distinction must be made between the exoteric or outer and the esoteric or inner dimensions of religion. Outwardly the doctrines of the world's religions are clearly different, even contradictory, as can be seen in their theologies. The Hindu tradition, for example, includes many Gods, Judaism insists there is only one God, and Buddhism declares the question of God to be moot. Or again, Christianity believes that God is a Trinity and that the divine Son was incarnate as Jesus Christ, beliefs explicitly rejected by Islam. According to the perennial 
philosophy, however, such outwardly divergent teachings, providentially adapted to the spiritual, psychological, and cultural needs of different peoples at different stages of history, can be inwardly reconciled by those who are sensitive to their metaphysical and symbolic meanings and prepared to follow the golden thread of the dogmatic letter to its deeper spiritual meaning. It is for this reason that one finds such a remarkable consensus among the greatest mystics and sages, such as Shankara in Hinduism, Ibn Arabi in Islam, and Meister Eckhart in Christianity.

The perennial philosophy may be classified as a kind of pluralism, though with two important qualifications. First, unlike many pluralists, perennial philosophers do not believe that every religious tradition is valid, but distinguish between true religions and their human or demonic counterfeits and, within authentic traditions, between orthodox and heretical forms. Some paths go all the way to the summit, but others circle aimlessly around the base of the mountain or lead away toward the desert. Second, where pluralism sees religion as resulting from human efforts to reach out to a divine Reality that can never be known as it is in itself, perennialism teaches that the world's true or orthodox religions are directly revealed by that Reality, each of them corresponding to an archetype within the divine mind. Revealed traditions do not communicate merely partial or complementary truths, which must then be combined by the syncretist to achieve a complete understanding. Rather, each is fully true in the sense that it provides its adherents with everything they need for reaching the highest or most complete human state, a state in which they will be able to confirm the truth experientially through their participation in the very nature of God.

It must be admitted that traditional Christianity is largely hostile to the perennial philosophy. In considering the claims of other religions, most Christians have been either exclusivists, denying the possibility of salvation to anyone outside the church, or inclusivists, extending the possibility of salvation only to those non-Christians who are invincibly ignorant of the Gospel but who belong to the church by their desire for salvation and benefit thereby from the redeeming work of the incarnate Son. But to say with perennialism that Christianity is but one among several revealed religions and that non-Christians can be saved independently of the events of the Gospel has seemed to most Christians a contradiction to their faith. Since Vatican II the Roman Catholic Church, for example, has adopted a primarily inclusivist stance, acknowledging the presence of certain partial truths in other religions, and yet in its declaration Dominus Iesus (2000) it explicitly repudiates the idea that there could be ways of salvation apart 
from Jesus Christ, whose historical passion, death, and resurrection are said to be the essential means of redemption for all.

According to Schuon and other perennialists, this dominant attitude among Christians is not surprising, nor should its usefulness for the vast majority of believers be called into question. The entire point of any religion is to ensure the salvation of as many people as possible, and most people, whether Christian or otherwise, are able to take their tradition seriously only if they are persuaded that it is the best, if not the only, way to reach God. Critics have argued that the New Testament, taken as a whole, is opposed to the perennial philosophy, and this is by and large true. Muslims could offer a parallel criticism, and they too would be correct in saying that the Qur'an, however positively it may sometimes speak about other People of the Book, nonetheless gives priority to those who follow the example of Muhammad. But for the perennialist this simply shows that the primary aim of the world's religions, beginning with their scriptures and apostolic authorities, is to assist their adherents in remaining focused on a single form of saving truth, not to lay the foundations for interfaith dialogue. On the other hand, given the common origin of the religions in a transcendent Source which, as the traditions themselves all attest, infinitely exceeds even its own self-expressions, it is in the nature of things that the scriptural and dogmatic formulations of each religion should include certain openings or clues to the underlying validity of the perennial philosophy. These clues may be found not simply on the periphery of religious traditions, but in their most central and essential doctrines.

This is certainly the case with Christianity, where one of the most important openings can be found in the traditional understanding of the Person of Christ. Christians who believe that their religion is either uniquely or decisively true often support their position by quoting Christ's words, 'I am the way, and the truth, and the life; no one comes to the Father but by me' (John 14:6). According to perennialist theologians, however, an exclusivist, or even inclusivist, interpretation of this and other such passages is by no means necessary and may in fact betray a heretical Christology. For in the developed doctrine of the ecumenical councils, the true person of Christ, that is, the subject who thinks his thoughts, speaks his words, and is the agent of all his actions, is the eternal Word or Son of God, the second Person of the Trinity. Jesus Christ is not a man who was adopted by God, nor a man in whom God was the indwelling presence, nor an intermediate being created by God as the highest of creatures, nor again a composite being who 
was partly divine and partly human. Who Jesus is, is the divine Son, 'of one essence with the Father', 'by whom all things were made' (Nicene Creed).

Of all the gospels, John is the most emphatic in this regard, for the same Person who says of himself that he is the only way to the Father also says that 'before Abraham was, I am' (John 8:58), a passage whose very tenses undercut the identification of Christ with a strictly temporal set of saving facts. Christian perennialists conclude that it is a mistake to confuse the uniqueness of the only-begotten and eternal Son of God with the alleged singularity of his historical manifestation in first-century Palestine. Without denying that there is only one Son of God, or that he alone is the author of salvation, or that Jesus Christ is that Son, they contend that there are no Biblical or dogmatic grounds for supposing that this one Son has limited his saving work to his incarnate presence as Jesus. On the contrary, as St Athanasius and other early fathers insisted, though the Word "became flesh and dwelt among us" (John 1:14), he was not confined by his body even during his earthly ministry.

It is sometimes objected that this line of reasoning drives a wedge between the two natures of Christ, diminishing the integrity and importance of the historical Jesus in favor of the Word or cosmic Christ. But this is to forget that a separate Jesus of history, understood as a particular man with a temporally conditioned psychology, is largely the invention of modern scholars, who are themselves often at odds with the very teachings that traditionalist Christians intend to safeguard. According to the fathers, especially those who interpreted the Council of Chalcedon (451) along the lines established by St Cyril of Alexandria, the Jesus of history is the cosmic Christ, for there is no historical person to be conceived alongside or in addition to the eternal Person of the only Son. Of course, the humanity of Jesus cannot be denied. 'Like us in all things except for sin' (Definition of Chalcedon), he was truly born, truly crucified, and truly raised from the dead. But in encountering this humanity what one encounters is not an individual human being — not some 'man of Nazareth' — but human nature as such, assumed into God and thus divinized.

Once this subtle point has been grasped, a number of other scriptural teachings begin to take on a more encompassing meaning. One reads in a new and fresh way that Christ is 'the true light who enlightens every man that comes into the world' (John 1:9), that he has 'other sheep who are not of this fold' (John 10:16), and that 'God shows no partiality, but in every nation any one who fears him and does what is right is acceptable to him' (Acts 10:34-35); and one notices 
that the events of Christ's passion on Golgotha are the working out at a particular time and place of a strictly timeless salvation, for the Lamb of God, whose 'act of righteousness leads to acquittal and life for all men' (Rom. 5:18), is 'slain from the foundation of the world' (Rev. 13:8). Following the thread of such clues, one begins to sense that the Son or Word, far from being limited to a single religion, is the divine principle behind all revelation and the eternal source of salvation in every authentic tradition. Though truly incarnate as Jesus Christ in Christianity, he is salvifically operative in and through non-Christian religions as well. In some he is present in an equally personal way, as in Krishna and the other Hindu avatars, in whom he was also 'made man' (Nicene Creed), while in others he appears in an impersonal way, as in the Qur'an of Islam, where he made himself book.

The concern is often expressed that a perennialist interpretation of Christianity has the effect of demoting Christ, making him only one among a variety of competing saviors. But if 'by their fruits' (Matt. 7:20) one may discern whether religions are valid and if the good fruit of sanctity is often found growing along non-Christian paths, it will perhaps seem instead that the power and scope of the Son of God are actually much greater than Christians had been led to believe, and the perennial philosophy will itself appear as a kind of inclusivism, but with an inclusivity no longer centered on Christianity or the church or its sacraments, but on Jesus Christ, the saving Source of all wisdom.

\section{Bibliography}

James S. Cutsinger, The Fullness of God: Frithjof Schuon on Christianity, Bloomington, Indiana: World Wisdom, 2004

, 'The Mystery of the Two Natures', in Barry McDonald (ed.), Every Branch in Me: Essays on the Meaning of Man, Bloomington, Indiana: World Wisdom, 2002

Whitall N. Perry, A Treasury of Traditional Wisdom, Louisville, Kentucky: Fons Vitae, 2001

Philip Sherrard, 'Christianity and Other Sacred Traditions' in Christianity: Lineaments of a Sacred Tradition, Brookline, Massachusetts: Holy Cross Orthodox Press, 1998 